\title{
Spatio-Temporal Analysis of Health Care Facilities in Allahabad District: A Geographical Study
}

\author{
Amit Kr. Singh ${ }^{1}$ Pawan Kr. Bhaskar ${ }^{2}$ Dr. V.K.Kumra ${ }^{3}$ \\ 1, Senior Research Fellow 2,Post-Doc. Fellow \& 3, ProfessorDepartment of Geography, Banaras Hindu \\ University, Varanasi \\ Email-vpamit87@gmail.com
}

\begin{abstract}
Health is the basic and primary need of an individual who makes the nation progress in socioeconomic, scientific, literary and cultural spheres. Health is both an input and output and is linked with development; therefore it should not be viewed in isolation from all goals of development. Provision of primary health care has dominant social and potential issues in many developed and developing countries. The services that are provided through health care system must meet the diverse need and demands of the people particularly living in rural areas of the country. The relevant data collected through purposive random sampling taken from health centres like community health centre, primary health centres and all the sub- centres. Distribution of healthcare facilities is almost regularly distributed across the district and shows no specific relationship with availability of transport network and nodes. The physical infrastructure of public healthcare institutions and health care personnel in Allahabad district do not appear to be substantially enough than the healthcare resources supplied to the less populated blocks in the district. There is need of additional $19 \mathrm{CHC}, 81 \mathrm{PHCs}$ and 335 Sub- centres should be opened in the Allahabad district to reduce the gap between existing and required facilities. This shows the urgent need to strongly emphasize the process of strengthening the infrastructural facilities at $\mathrm{CHCs} / \mathrm{PHCs}$ to utilize their full potential in the study area.
\end{abstract}

\section{INTRODUCTION}

Health is an integral part of development. The health care is an important element of well-being, yet it has been one of the most neglected aspects of development in India (Drazee and Sen, 2005). Just as health status is influenced by the socio-economic factors, similarly health services are shaped by the socio-economic and political factors of any region (Baru et. al., 2010). Inequality in the distribution of health care facility is a common manifestation of these factors and a general feature of health care system in India. According to Rajeshwari and Sinha (2004), the distribution of health care institutions in India is guided by location preferences. A steady improvement in the health status of population is being observed by continuous efforts and innovations in health sectors but still much has to be done to be at par with the national status of health in state. The effects of health activities so far taken is more in urban than rural areas due to illiteracy and poverty. So in rural areas major health care indicators are on a lower side than urban areas specially incase of infant mortality, maternal mortality and nutritional status of children, for which special attention is being paid in these region during the Eleventh Plan Period.

For analyzing the utilization pattern of health care facilities, an assessment of distribution of health care facilities and availability of infrastructures on these health care centres is essential. If the distribution of health care centres is adequate enough in any area, it means the concerned area has made considerable progress in terms of medical services and that can provide good health services to its people. In view of this background, health care system, public health care network, social indicators, distribution of health care facilities along with various components of physical health care facilities available at health care centres have been dealt in this chapter. Some Indian scenarios related to health care centres and facilities have also been described as an introductory part.

\section{STUDY AREA}

The district of Allahabad is extend between $24^{\circ} 47^{\prime} \mathrm{N}$ and $25^{\circ} 47^{\prime} \mathrm{N}$ latitudes and between $81^{\circ} 19^{\prime} \mathrm{E}$ and $82^{0} 30^{\prime}$ E longitudes. It covers an area of $5,246 \mathrm{~km}^{2}$. Allahabad district is in the southern part of Uttar Pradesh. The northern part of the district is in the Gangetic Plain and southern part is in Vindhyan Plateau. To its south and southeast is the Bagelkhand region, to its north and northeast is the Awadh region, and to its west along with Kaushambi it forms the part of Doab i.e. the lower Doab region. Allahabad District is surrounded by district Bhadohi and Mirzapur in the east, Kaushambi and Banda in the west, Pratapgarh and Jaunpur in the north and Banda and Madhya Pradesh are in the south. River Ganga and Yamuna flow through the district. 


\section{OBJECTIVES}

Keeping the above facts in mind the present paper aims at analyzing

- To know the pattern of health infrastructures and health care services available at CHC, PHCs and Subcentres.

- To assess the required number of health care facilities in the study area.

\section{DATA BASE AND METHODOLOGY}

The present study is based on primary and secondary data obtained from different sources. Secondary data have been collected from the census handbook of the Allahabad district and district statistical year books and some information from block headquarters. Data regarding the availability of different types of health care facilities at CHC, PHCs, and Sub- centres were obtained by personal survey conducted during 2014-15.

\section{HEALTH CARE SYSTEM- STRUCTURE AND CURRENT SCENARIO}

Health care in India is delivered through a three tier structure of health services comprising of primary, secondary and tertiary health care facilities with the objective of bringing health care services within the reach of the people of both the rural and urban areas. The primary tier healthcare system would have three types of health care institutions, namely, a Sub-centre (SC) for a population of 3,000-5,000, a Primary Health Centre (PHC) for 20,000 to 30,000 population and a Community Health Centre (CHC) for 1,20,000 population as referral centre for every four PHCs. The district hospitals are to function as the secondary tier healthcare system for the urban population. The tertiary health care is to be provided by health care institutions in urban areas which are well equipped with sophisticated diagnostic and investigative facilities.

The Indian HealthCare system is a three-tire structure which focuses on delivering healthcare at the individual level. This structure is designed according to the size of population (Table 1.1).

Table 1.1: Population norm for establishment of health care centres

\begin{tabular}{|c|c|c|}
\hline \multirow[t]{2}{*}{ Centre } & \multicolumn{2}{|c|}{ Population norm } \\
\hline & Plain area & Hilly/ Tribal area \\
\hline Sub-Centre & 5,000 & 3,000 \\
\hline PHC & 30,000 & 20,000 \\
\hline $\mathrm{CHC}$ & 120,000 & 80,000 \\
\hline
\end{tabular}

Source: Chief Medical Officer, Allahabad District, 2015.

Sub Centres (SCs): The Sub Centre is the most peripheral and first contact point between the primary health care system and the community. Sub Centres are assigned the tasks relating to interpersonal communication in order to bring about behavioral change and provide services in relation to Maternal and Child Health (MCH), family welfare, nutrition, immunization, diarrhoea control and control of communicable diseases programmes. Under the Swap Scheme, the Government of India has taken over an additional 39,554 Sub Centres from State governments / Union territories since April, 2002 in lieu of 5,434 Rural Family Welfare Centres transferred to the State governments / Union territories. There were 1,53,655 Sub Centres functioning in the country as on 31st March, 2015.

Primary Health Centres (PHCs): PHC is the first contact point between village community and the medical officer. The PHCs were envisaged to provide an integrated curative and preventive health care to the rural population with emphasis on preventive and promotive aspects of health care. It acts as a referral unit for 6 Sub Centres and has 4 - 6 beds for patients. The activities of PHC involve curative, preventive, promotive and family welfare services. There were 25,308 PHCs functioning in the country as on 31st March, 2015.

Community Health Centres (CHCs): As per minimum norms, a $\mathrm{CHC}$ is required to be manned by four medical specialists i.e. surgeon, physician, gynecologist and pediatrician supported by 21 paramedical and other staff. It has 30 in-door beds with one OT, X-ray, labour room and laboratory facilities. It serves as a referral centre for 4 PHCs and also provides facilities for obstetric care and specialist consultations. As on 31st March, 2015, there were 5,396 CHCs functioning in the country. The State Government manages a vast network of health facilities. It consist of 20,521 sub centers, 3,692 P.H.C., 515 C.H.C, 191 District and Other hospitals, 3 Super Specialty Hospital and 9 Medical Collage to provide a range of preventive and curative health services to the public (Table 1.2). These facilities have been set according to 1991 Censes population norms and are being upgraded to provide services as per Indian Public Health Standard. Special attention is being paid on cleanliness, safe water supply, clean toilets and 24 hour electric supply. Arrangements are being made for stay of attendants in hospitals and prompt delivery of services. However, despite this vast network, access to the targets stands as one of barriers in upgrading the health services. 
Spatio-Temporal Analysis Of Health Care Facilities in Allahabad District: A Geographical Study

Table 1.2: Healthcare Infrastructure in Uttar Pradesh

\begin{tabular}{|l|l|l|}
\hline S1. No. & Unit & Number \\
\hline 1 & District Male Hospitals & 78 \\
\hline 2 & District Female Hospitals & 71 \\
\hline 3 & Other Hospitals & 42 \\
\hline 4 & Community Health Centres (CHCs) & 515 \\
\hline 5 & Primary Health Centres (PHCs) & 3692 \\
\hline 6 & Sub-centres (SCs) & 20521 \\
\hline
\end{tabular}

Source: Chief Medical Officer, Allahabad district, Uttar Pradesh, 2015.

The State government is conscious of the inadequacies in solving the health problems of the state. There is substantial scope for improvement in patient care in healthcare centres. For this purpose, the infrastructure is being strengthened in district hospitals, CHCs, PHCs sub centers and various training centers. Attempts are also being made to provide hi-tech equipments in hospitals. The State government has established two Trauma Centers at Shahjahanpur and Raebareilly which are functioning and 06 more Trauma Centers at Lalitpur, Etawah, Jalaun, Faizabad, Basti and Fatehpur are under process of construction. Besides, highway ambulance services are being made functional which will certainly benefit to road-accident victims. Mobile Medical Units for distant and hard to reach areas are also coming up under State's Programme Implementation Plan (PIP) of 2010- 2011. These institutions are also engaging human resources on contract basis. For capacity building of functionaries and medical officers for skill development and better performance, the department has started short term training programmes for medical officers and para medical staff. Health care in UP can be summarized as a composite challenge of access, quality and demand. The large public sector does not have adequate access besides being found wanting in the quality of care at the cutting edge (PHCs and Sub-Centers). The overall organizational structure and system of public health care provision are not very different across the country. Even though health is a state subject and most states follow a similar pattern of health care administration and management. This is largely because of a common planning framework, which is governed by the Planning Commission and National Development Council (Duggal, Ravi and et. all 2005).

The health services may be analyzed in terms of the community for which they serve and deal with. These services are the integral part of a particular health system and represent responses to the health concern and to the health needs. But it has been found that the localization of the community to which they serve and hence unequal distribution of medical facilities are observed in any region (Pandurkar, R.G. 1981).

It is not surprising that there is a tremendous pressure on existing health care system to meet the need of vast population of the study area Hence an assessment of available resources is imperative for proper allocation and efficient utilization of health care services. In this chapter attempt has been made to analyze the spatio-temporal distribution of health care facilities available in Allahabad district. The units like Hospitals/Dispensaries, Community Health Centres (CHCs), Primary Health Centers (PHCs), Sub-centers (SCs), number of Doctors, Beds, Para-medical Staffs and Other Staffs available in the study area are also considered for this study.

Table 1.3: Distribution of Healthcare Facilities across Blocks (2015)

\begin{tabular}{|c|c|c|c|c|c|c|c|}
\hline \multicolumn{8}{|c|}{ Distribution of Healthcare Facilities across Blocks (2015) } \\
\hline Block Name & \multicolumn{4}{|c|}{ Allopathic } & \multirow[t]{2}{*}{ Ayurvedic } & \multirow[t]{2}{*}{ Homeopathic } & \multirow[t]{2}{*}{ Unani } \\
\hline & Hospital/Dispensaries & CHCs & PHCs & $\begin{array}{c}\text { Sub- } \\
\text { centres }\end{array}$ & & & \\
\hline Kaurihar & 1 & 1 & 5 & 36 & 4 & 2 & 2 \\
\hline Holagarh & 1 & 0 & 2 & 28 & 1 & 0 & 0 \\
\hline Mauaima & 3 & 1 & 3 & 26 & 1 & 1 & 1 \\
\hline Soraon & 1 & 1 & 3 & 25 & 1 & 2 & 0 \\
\hline Bahria & 0 & 1 & 3 & 34 & 2 & 0 & 0 \\
\hline Phulpur & 2 & 1 & 2 & 28 & 0 & 1 & 1 \\
\hline Bahadurpur & 0 & 1 & 6 & 38 & 1 & 3 & 0 \\
\hline Pratappur & 0 & 1 & 5 & 28 & 2 & 2 & 0 \\
\hline Saidabad & 0 & 1 & 6 & 26 & 1 & 0 & 0 \\
\hline Dhanupur & 0 & 1 & 4 & 24 & 2 & 0 & 0 \\
\hline Handia & 2 & 1 & 5 & 23 & 3 & 1 & 0 \\
\hline Jasra & 1 & 1 & 3 & 30 & 3 & 1 & 0 \\
\hline Shankargarh & 1 & 1 & 3 & 30 & 0 & 6 & 0 \\
\hline Chaka & 0 & 1 & 2 & 26 & 2 & 1 & 0 \\
\hline Karchhana & 3 & 1 & 3 & 29 & 2 & 3 & 0 \\
\hline Kaudhiyara & 1 & 1 & 1 & 24 & 0 & 0 & 0 \\
\hline Uruwan & 1 & 1 & 3 & 27 & 0 & 1 & 0 \\
\hline
\end{tabular}


Spatio-Temporal Analysis Of Health Care Facilities in Allahabad District: A Geographical Study

\begin{tabular}{|l|c|c|c|c|c|c|c|}
\hline Meja & 0 & 1 & 3 & 28 & 3 & 0 & 0 \\
\hline Koraon & 1 & 1 & 5 & 34 & 1 & 1 & 0 \\
\hline Manda & 1 & 1 & 3 & 28 & 1 & 1 & 0 \\
\hline Total & $\mathbf{1 9}$ & $\mathbf{1 9}$ & $\mathbf{7 0}$ & $\mathbf{5 7 2}$ & $\mathbf{3 0}$ & $\mathbf{2 6}$ & $\mathbf{4}$ \\
\hline
\end{tabular}

Source: Based on Secondary data collected from CMO office Allahabad District as on march 2015.

\section{DISTRIBUTION OF HEALTHCARE FACILITIES} IN ALLAHABAD DISTRICT

The existing government healthcare centers can be organized in different hierarchical order as the Health Sub Centre, Primary Health Centre including Community health care, General Hospitals, District Hospitals. These are located on the basis of economic feasibility and requirement by the people. The spatial distribution of healthcare centers is uneven as the human population on the earth's surface and the factors for such uneven distribution of health centres is almost similar. The uneven distribution of health centers are observed even at micro level not only between the regions but within the region also, depending upon the demand of the health care institutions and the supply of the patients. The public health institutions of the Allahabad district comprises of four district hospitals, one Tuberculosis hospital, nineteen Community Health Centers, seventy Primary Health Centers, including new PHCs and 572 Sub-centers. Besides, there are 30 Ayurvedic, 26 Homeopathic and 4 Unani hospitals/dispensaries for providing healthcare services to the people. Development block wise distribution of healthcare facilities is given in Table 1.3.

As for as the spatial analysis of healthcare facilities is concerned, it can be made at block levelin relation to $\mathrm{PHCs} / \mathrm{CHCs}$ which shows huge gap between existing and required facilities. The highest number of PHCs is found in Bahadurpur (6), Saidabad (6), followed by Kaurihar (5), Pratappur (5), Handia (5) and Koraon (5) development blocks. Kaudhiyara (1), Chaka (2), Phulpur (2) and Holagarh (2) development blocks have less number of PHCs. All the blocks have one CHC except Holagarh. It is clear from the Table 1.3 that hospitals and dispensaries are mostly confined in urban areas. Sub-centres are supposed to play an important role in keeping good health of the people specially for women and childrens of countryside, therefore, it is essential to analyze their distributional pattern. The considerable number of sub-centres are found in Kaurihar (36), Koraon (34), Jasra (30), Shankargarh (30) whereas, Handia (23), Dhanupur (24), Kaudhiyara (24), and Soraon (25) development blocks endowed with poor infrastructure. The distribution of homeopathic hospitals/dispensaries is mainly confined in Kaurihar (4), Handia, Jasra (3) and Meja (3) block. Whereas, Kaudhiyara, Uruwan, Shankargarh and Phulpur have not a single Ayurvedic healthcare centre available. Out of the total 4 Unani hospitals two are located in Kaurihar and one each in Mauima and Phulpur blocks.

The techniques of Homeopathy treatment is based on the basic principle of 'samah samae samyati' and helps patients stay free of diseases. Homeopathy gives better medical facilities at low prices and wipes the disease from its root. Due to all these qualities and the fact that it is effective immediately without any adverse effects on health makes it very popular among the rural public. It is very useful to poor people especially to those who are below the poverty line and whose expenditure ability is very low. Consequently, the level of acceptance towards homeopathy is increasing rapidly among the people. Homeopathic hospitals are also not equally distributed over the study area. Out of the total 26 homeopathy health centres mostly concentrated in Shankargarh (6), Karchhana (3) and Phulpur (3) development blocks. This facility is not available in all the development blocks.Distribution of healthcare facilities is almost regularly distributed across the district and shows no specific relationship with availability of transport network and nodes. It means that remote villages located away from the transport nodes and major roads should also possess some kind of healthcare facilities.

\section{GROWTH OF HEALTHCARE FACILITIES}

Growth and accessibility of healthcare facilities of any region provide opportunities to basic healthcare system and universal coverage of health for all. Healthcare infrastructure is an important indicator for understanding the healthcare policy and welfare mechanism in a country. It also reflects country's priority with regards to the establishment of new facilities and improvement in the available infrastructure. Table 1.4 shows the decadal growth of healthcare facilities during 1994-2004 and 2004-2014 of Allahabad district. The study of the growth of healthcare facilities in the district is explained through differential found in basic infrastructure, medical personal and other paramedical staff during the above mentioned two decades. The growth of different systems and segments of healthcare facilities have changed in both the decades. 
Table 1.4: Temporal Change in Healthcare Facilities from $1994-2014$

\begin{tabular}{|c|c|c|c|c|c|c|c|c|c|c|}
\hline & & \multicolumn{9}{|c|}{ Temporal Change in Healthcare Facilities } \\
\hline & & \multicolumn{3}{|c|}{ Existing Facilities } & \multicolumn{2}{|c|}{ 1994-2004 } & \multicolumn{2}{|c|}{ 2004-2014 } & \multicolumn{2}{|c|}{ 1994-2014 } \\
\hline & & 1994 & 2004 & 2014 & Number & $\begin{array}{l}\text { Per } \\
\text { cent }\end{array}$ & Number & $\begin{array}{l}\text { Per } \\
\text { cent }\end{array}$ & Number & $\begin{array}{l}\text { Per } \\
\text { cent }\end{array}$ \\
\hline \multirow[t]{9}{*}{ Allopathic } & & & & & & & 0 & & & \\
\hline & Hospitals/Dispensaries & 19 & 19 & 19 & 0 & 0.00 & & 0.00 & 0 & 0.00 \\
\hline & $\mathrm{CHCs}$ & 0 & 13 & 19 & 13 & 100.00 & 6 & 31.58 & 19 & 100.00 \\
\hline & PHCs & 78 & 81 & 70 & 3 & 3.70 & -11 & -15.71 & -8 & -10.26 \\
\hline & Sub-centers & 427 & 531 & 572 & 104 & 19.59 & 41 & 7.17 & 145 & 33.96 \\
\hline & Beds & 729 & 684 & 662 & -45 & -6.58 & -22 & -3.32 & -67 & -9.19 \\
\hline & Doctors & 187 & 112 & 179 & -75 & -66.96 & 67 & 37.43 & -8 & -4.28 \\
\hline & Para-Medical Staffs & 160 & 165 & 367 & 5 & 3.03 & 202 & 55.04 & 207 & 129.38 \\
\hline & Others & 223 & 222 & 655 & -1 & -0.45 & 433 & 66.11 & 432 & 193.72 \\
\hline \multirow[t]{4}{*}{ Ayurvedic } & & & & & & & 0 & & & \\
\hline & Hospital \& Dispensary & 19 & 30 & 30 & 11 & 36.67 & & 0.00 & 11 & 57.89 \\
\hline & Beds & 136 & 140 & 136 & 4 & 2.86 & -4 & -2.94 & 0 & 0.00 \\
\hline & Doctors & 27 & 29 & 25 & 2 & 6.90 & -4 & -16.00 & -2 & -7.41 \\
\hline \multirow[t]{4}{*}{ Homeopathic } & & & & & & & 0 & & & \\
\hline & Hospital \& Dispensary & 20 & 26 & 26 & 6 & 23.08 & & 0.00 & 6 & 30.00 \\
\hline & Beds & 0 & 0 & 0 & 0 & 0.00 & 0 & 0.00 & 0 & 0.00 \\
\hline & Doctors & 20 & 26 & 25 & 6 & 23.08 & -1 & -4.00 & 5 & 25.00 \\
\hline \multirow[t]{4}{*}{ Unani } & & & & & & & 0 & & & \\
\hline & Hospital \& Dispensary & 4 & 4 & 4 & 0 & 0.00 & & 0.00 & 0 & 0.00 \\
\hline & Beds & 12 & 12 & 12 & 0 & 0.00 & 0 & 0.00 & 0 & 0.00 \\
\hline & Doctors & 4 & 4 & 2 & 0 & 0.00 & -2 & $\begin{array}{c}- \\
100.00\end{array}$ & -2 & -50.00 \\
\hline
\end{tabular}

Source: Secondary data collected from District Statistical Handbook of Allahabad (Year 1994, 2004, 2014) and analysed by researcher.

Table 1.4 shows that the during 1995-2005 the Allopathic facilities have increased in terms of number of PHCs by 3.7 per cent, Sub-centres also increased by 19.59 per cent. The Para-medical staff has increased by 3.03 per cent, while the number of doctors has decreased to 66.96 per cent. It has also been found that number of total beds has decreased from 729 in 1995 to 684 bed in 2005. The hospitals/dispensaries remained constant in the study area during 1995-2005. Contrary to this, number of CHCs has increased from zero in 1995 to thirteen in 2005. Similarly, Ayurvedic healthcare facilities such as hospitals/dispensaries have increased by 36.67 per cent, number of beds by 2.86 per cent and the doctors with 6.90 per cent during the same time period. The number of Homeopathic healthcare centres shows an increase from 20 to 26 in 1995 . Unani systems of healthcare facilities have stagnant growth in terms of hospitals and beds, while number of doctors in Unani hospitals have negative growth $(-2 \%)$. The temporal growth of the previously mentioned health related parameters exhibits some interesting findings. During the period of 2004-2014, all the indicators show a patterned development. Above analysis shows that the decadal growth during 2004-2014 period of Allopathic facilities have increased in respect to number of CHCs from 13 to 19 (31.58\%), Sub-centres increased by 7.17 per cent, Para-medical staffs by 55.04 per cent, while the number of doctors have reported negative growth during previous decade have increased during 2004-2014 upto 37.43 per cent and others staff have also increased from 222 to 655 (66.11\%). Contrary to this, the number of PHCs have decreased from 81 in 2004 to 70 in $2014(-15.71 \%)$ because most of the PHCs have upgraded CHCs during this decade. The number of beds has decreased $(-3.22 \%)$. However, there is found some positive growth in Allopathic in terms of physical infrastructure and human resources but it is not sufficient to serve the whole population of the study area adequately. Beside this, hospitals/dispensaries of Ayurvedic, Homeopathic and Unani systems have recorded zero growth and remained stagnant during this decade while numbers of beds and doctors in Ayurvedic hospitals/dispensaries have decreased by 4 per cent against the existing situation during previous decade. Similarly, number of doctors in Homeopathic and Unani have also decreased from 26 to 25 (-4\%) and 4 to 2 ($50 \%$ ) respectively.

\section{DISTRIBUTION OF HEALTHCARE FACILITIES IN TERMS OF POPULATION}

Health is the basic necessity of people and accessible medical facilities need to be available for the entire population. However, differences are observed with respect to the population served per Government hospital. A comparison of these parameters across development blocks is shown in Table 1.5.

Medical institution-population ratio: It is the expression of number of medical institutions (includes Community Health Centers, Block Primary Health Centers, Government Hospitals, etc.) per lakh of population 
in different blocks of the district. This is perhaps the most important indicator in relation to the medical facility of a particular region. Increasing number of health centers always increases the probability of fast remedy from health related problems. But only a quantitative assessment such as the number of medical institution is not enough for the desired result, rather a quality assessment in terms of properly equipped medical centers (i.e. health related infrastructure) for better treatment facility is the most important. In case of Allahabad district, block level disparities exist in terms of Medical institution-population ratio. Average number of medical institution available per lakh population in 1994 was 3.45 which have gradually decreases $3 /$ lakh population in 2004 and 2.88/lakh population in 2014. In fact the availability of medical institution has increased very slightly during the period 1994-2014. It is interesting to note that the availability of the medical institutions in terms of per lakh population gradually decreasing during 1994-2014 in Jasra (6.23 to 2.91/lakh population), Shankargarh (5.85 to 3.06/lakh population), Manda (5.97 to 2.53/lakh population) and Soraon (4.50 to 2.59/lakh population), whereas, improvement has been observed in Dhanupur (1.98-2.15/lakh population), whereas, improvement has been observed in Dhanupur (1.98 to 2.15/lakh population), Handia (3.63 to 3.76/lakh population) and Pratppur (2.66 to 2.67 institution per lakh population) blocks. Although, with the increase in population, the healthcare facilities should also increase in number yet the scenario is quite different. For the district as a whole the number of medical institutions per lakh population has been worked out as 3.45. Out of total 20 development blocks, 50 per cent of the blocks are behind the district average. These blocks are Holagarh, Mauaima, Bahria and Chaka.

Sub centers-population ratio: It includes both the number of family welfare centers and the sub centers per thousand of population. This is the most peripheral and first contact point between the primary health care system and the community. The availability of these indicates the basic structure of rural health care and increasing number of such centers always promote better awareness and primary first-aid treatment to the local inhabitants. Availability of sub-centres in the district was $15.20 /$ lakh population in the year 1994. Dimension Index of this parameter stated the same story. Performance of Jasra (22.24 sub-centres/lakh population) block regarding this parameter stands highest.

Table 1.5: Availability of Healthcare Facilities/Lakh Population across the Development Blocks (1994 2014)

\begin{tabular}{|c|c|c|c|c|c|c|c|c|c|c|c|c|c|c|c|c|c|c|}
\hline \multirow{3}{*}{$\begin{array}{l}\text { Block } \\
\text { Name }\end{array}$} & \multicolumn{18}{|c|}{ Healthcare Facilities/Lakh Population (1994 - 2014) } \\
\hline & \multicolumn{6}{|c|}{1994} & \multicolumn{6}{|c|}{2004} & \multicolumn{6}{|c|}{2014} \\
\hline & I & $\mathbf{S}$ & $\mathbf{B}$ & D & $\mathbf{P}$ & $\mathbf{O}$ & $\mathbf{I}$ & $\mathbf{S}$ & $\mathbf{B}$ & D & $\mathbf{P}$ & $\mathbf{O}$ & $\mathbf{I}$ & $\mathbf{S}$ & B & D & $\mathbf{P}$ & $\mathbf{O}$ \\
\hline \multirow{2}{*}{$\begin{array}{l}\text { Kauri } \\
\text { har }\end{array}$} & 4.2 & 14. & 18. & 5.6 & 5.6 & 7.0 & 1.8 & 12. & 6.4 & 1.0 & 2.6 & 3.2 & 1.7 & 9.1 & 11. & 3.3 & 4.8 & 13. \\
\hline & 3 & 80 & 32 & 4 & 4 & 5 & 8 & 38 & 6 & 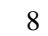 & 9 & 3 & 8 & 5 & 18 & 0 & 3 & 72 \\
\hline \multirow{2}{*}{$\begin{array}{l}\text { Holag } \\
\text { arh }\end{array}$} & 2.3 & 17. & 11. & 4.7 & 6.3 & 6.3 & 1.9 & 16. & 5.1 & 1.3 & 5.1 & 5.1 & 1.6 & 15. & 3.2 & 1.6 & 6.0 & 22. \\
\hline & 9 & 55 & 17 & 9 & 8 & 8 & 4 & 85 & 8 & 0 & 8 & 8 & 4 & 33 & 8 & 4 & 2 & 44 \\
\hline \multirow{2}{*}{$\begin{array}{l}\text { Mauai } \\
\text { ma }\end{array}$} & 2.5 & 17. & 11. & 4.2 & 4.2 & 6.7 & 4.6 & 16. & 10. & 3.3 & 3.3 & 5.3 & 3.7 & 13. & 20 . & 5.9 & 8.6 & 22. \\
\hline & 4 & 78 & 85 & 3 & 3 & 7 & 8 & 73 & 71 & 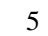 & 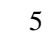 & 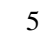 & 7 & 99 & 45 & 2 & 1 & 06 \\
\hline \multirow{2}{*}{$\begin{array}{l}\text { Sorao } \\
\mathrm{n}\end{array}$} & 4.5 & 12. & 60. & 8.9 & 5.9 & 9.7 & 3.5 & 12. & 27. & 6.5 & 4.7 & 7.1 & 2.5 & 12. & 18. & 4.6 & 10. & 24. \\
\hline & 0 & 74 & 69 & 9 & 9 & 4 & 6 & 45 & 27 & 2 & 4 & 1 & 9 & 94 & 64 & 6 & 87 & 33 \\
\hline \multirow[b]{2}{*}{ Bahria } & 1.6 & 14. & 6.6 & 4.4 & 4.4 & 5.5 & 1.3 & 14. & 5.2 & 1.3 & 3.5 & 4.4 & 1.4 & 12. & 13. & 2.9 & 5.1 & 15. \\
\hline & 6 & 90 & 2 & 1 & 1 & 2 & 2 & 07 & 8 & 2 & 2 & 0 & 7 & 46 & 93 & $J$ & 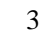 & 40 \\
\hline \multirow{2}{*}{$\begin{array}{l}\text { Phulp } \\
\text { ur } \\
\end{array}$} & 3.3 & 14. & 18. & 8.0 & 5.3 & 6.6 & 3.1 & 13. & 21. & 4.1 & 5.2 & 5.2 & 2.2 & 12. & 15. & 4.4 & 8.0 & 14. \\
\hline & 4 & 67 & 68 & 0 & 4 & 7 & 4 & 07 & 96 & 8 & 3 & 3 & 2 & 44 & 11 & 4 & 0 & 67 \\
\hline \multirow{2}{*}{$\begin{array}{l}\text { Bahad } \\
\text { urpur }\end{array}$} & 2.8 & 14. & 11. & 3.8 & 3.8 & 5.7 & 2.4 & 12. & 9.7 & 2.4 & 3.2 & 4.4 & 2.3 & 12. & 4.7 & 4.0 & 5.0 & 16. \\
\hline & 8 & 89 & 53 & 4 & 4 & 7 & 3 & 94 & 0 & 3 & 3 & 5 & 1 & 86 & 4 & 6 & 8 & 24 \\
\hline \multirow{2}{*}{$\begin{array}{l}\text { Pratap } \\
\text { pur }\end{array}$} & 2.6 & 14. & 10. & 5.3 & 4.6 & 6.6 & 2.6 & 13. & 10. & 2.6 & 3.7 & 5.3 & 2.6 & 12. & 18. & 4.4 & $\begin{array}{l}5.3 \\
\end{array}$ & 12. \\
\hline & 6 & 63 & 64 & 2 & 6 & 5 & 7 & 37 & 70 & 7 & 4 & 5 & 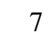 & 46 & 69 & 5 & 4 & 46 \\
\hline \multirow{2}{*}{$\begin{array}{l}\text { Saida } \\
\text { bad }\end{array}$} & 3.0 & 12. & 12. & 4.8 & 4.8 & 6.0 & 2.3 & 11. & 9.5 & 2.3 & 3.3 & 4.7 & 2.7 & 10 . & 4.7 & 2.7 & 7.1 & 10 . \\
\hline & 0 & 02 & 02 & 1 & 1 & 1 & 8 & 45 & 4 & 8 & 4 & 7 & 6 & 27 & 4 & 6 & 1 & 27 \\
\hline \multirow{2}{*}{$\begin{array}{l}\text { Dhanu } \\
\text { pur }\end{array}$} & 1.9 & 13. & 7.9 & 3.9 & 5.2 & 6.6 & 2.0 & 12. & 8.3 & 2.0 & 3.6 & 5.2 & 2.1 & 10. & 17. & 3.8 & 6.0 & 9.4 \\
\hline & 8 & 21 & 3 & 6 & 8 & 0 & 9 & 56 & 8 & 9 & 6 & 4 & 5 & 32 & 21 & 7 & 2 & 6 \\
\hline \multirow{2}{*}{$\begin{array}{l}\text { Handi } \\
\text { a }\end{array}$} & 3.6 & 13. & 34. & 8.7 & 5.8 & 7.2 & 5.2 & 12. & 31. & 5.8 & 5.2 & 6.9 & 3.7 & 10. & 18. & 6.1 & 12. & 14. \\
\hline & 3 & 06 & 83 & 1 & 1 & 6 & 3 & 20 & 36 & 1 & 3 & 7 & 6 & 82 & 82 & 2 & 70 & 58 \\
\hline \multirow[t]{2}{*}{ Jasra } & 6.2 & 22. & 49. & 10. & 10. & 14. & 4.8 & 20 . & 34. & 5.5 & 8.3 & 9.7 & 2.9 & 17. & 20 . & 5.8 & 11. & 19. \\
\hline & 3 & 24 & 82 & 68 & 68 & 24 & 9 & 25 & 91 & 9 & 8 & 7 & 1 & 47 & 97 & 2 & 07 & 22 \\
\hline \multirow{2}{*}{$\begin{array}{l}\text { Shank } \\
\text { argarh }\end{array}$} & 5.8 & 21. & 52. & 11. & 7.8 & 13. & 3.6 & 19. & 31. & 2.2 & 5.9 & 10. & 3.0 & 18. & 20 . & 5.5 & 11. & 12. \\
\hline & 5 & 44 & 62 & 69 & 0 & 64 & 9 & 19 & 00 & 1 & 0 & 33 & 6 & 35 & 79 & 0 & 62 & 84 \\
\hline \multirow[b]{2}{*}{ Chaka } & 1.5 & 14. & 26. & 6.2 & 6.2 & 7.8 & 2.8 & 15. & 29. & 7.7 & 5.6 & 7.0 & 1.3 & 11. & 15. & 3.6 & 14. & 18. \\
\hline & 7 & 14 & 71 & 9 & 9 & 6 & 2 & 49 & 57 & 4 & 3 & 4 & 6 & 79 & 42 & 3 & 06 & 60 \\
\hline \multirow{2}{*}{$\begin{array}{l}\text { Karch } \\
\text { hana }\end{array}$} & 3.2 & 13. & 28. & 5.1 & 6.4 & 6.4 & 3.5 & 10. & 20. & 2.6 & 4.4 & 4.0 & 2.9 & 12. & 15. & 4.6 & 9.7 & 13. \\
\hline & 3 & 55 & 40 & 6 & 5 & 5 & 8 & 30 & 59 & 9 & 8 & 3 & 7 & 31 & 28 & 7 & 6 & 58 \\
\hline Kaudh & 4.0 & 19. & 38. & 8.0 & 8.0 & 10. & 2.3 & 20. & 27. & 3.9 & 6.3 & 7.1 & 1.8 & 15. & 20. & 3.7 & 8.7 & 12. \\
\hline iyara & 3 & 15 & 30 & 6 & 6 & 08 & 9 & 67 & 03 & 8 & 6 & 6 & 8 & 03 & 04 & 6 & 7 & 52 \\
\hline Uruw & 3.8 & 12. & 36. & 9.1 & 4.5 & 9.1 & 3.6 & 13. & 27. & 3.6 & 4.8 & 6.6 & 2.4 & 13. & 17. & 4.4 & 9.3 & 11. \\
\hline an & 1 & 94 & 53 & 3 & 7 & 3 & 2 & 27 & 74 & 2 & 2 & 3 & 6 & 26 & 68 & 2 & 3 & 79 \\
\hline & 4.2 & 18. & 39. & 10. & 6.8 & 10. & 3.7 & 17. & 28. & 1.8 & 5.0 & 7.5 & 2.0 & 14. & 18. & 2.5 & 7.6 & 12. \\
\hline Meja & 6 & 76 & 22 & 23 & 2 & 23 & 7 & 61 & 94 & 9 & 3 & 5 & 3 & 21 & 27 & 4 & 1 & 18 \\
\hline
\end{tabular}


Spatio-Temporal Analysis Of Health Care Facilities in Allahabad District: A Geographical Study

\begin{tabular}{|c|c|c|c|c|c|c|c|c|c|c|c|c|c|c|c|c|c|c|}
\hline Korao & 3.8 & 10. & 30. & 6.5 & 4.3 & 8.7 & 3.0 & 12. & 22. & 1.7 & 3.5 & 7.0 & 2.2 & 10. & 12. & 2.5 & 6.9 & 8.8 \\
\hline $\mathrm{n}$ & 3 & 94 & 63 & 6 & 8 & 5 & 8 & 32 & 00 & 6 & 2 & 4 & 1 & 73 & 00 & 3 & 5 & 4 \\
\hline Mand & 5.9 & 18. & 49. & 8.5 & 6.8 & 10. & 3.3 & 14. & 25. & 1.6 & 4.4 & 7.7 & 2.5 & 14. & 18. & 4.0 & 10. & 9.6 \\
\hline $\mathrm{a}$ & 7 & 76 & 47 & 3 & 2 & 23 & 3 & 44 & 55 & 7 & 4 & 7 & 3 & 18 & 24 & 5 & 13 & 2 \\
\hline Total & $\begin{array}{r}3.4 \\
5\end{array}$ & $\begin{array}{r}15 . \\
20\end{array}$ & $\begin{array}{r}25 . \\
95\end{array}$ & $\begin{array}{r}6.6 \\
6\end{array}$ & $\begin{array}{r}5.7 \\
0\end{array}$ & $\begin{array}{r}7.9 \\
4\end{array}$ & $\begin{array}{r}3.0 \\
0\end{array}$ & $\begin{array}{r}14 . \\
08\end{array}$ & $\begin{array}{r}18 . \\
13\end{array}$ & $\begin{array}{r}2.9 \\
7\end{array}$ & $\begin{array}{r}4.3 \\
7\end{array}$ & $\begin{array}{r}5.8 \\
9\end{array}$ & $\begin{array}{r}2.3 \\
8\end{array}$ & $\begin{array}{r}12 . \\
61\end{array}$ & $\begin{array}{r}14 . \\
59\end{array}$ & $\begin{array}{r}3.9 \\
5\end{array}$ & $\begin{array}{r}8.0 \\
9\end{array}$ & $\begin{array}{r}14 . \\
44\end{array}$ \\
\hline
\end{tabular}

Source: Calculated by the researcher from Statistical Handbook of Allahabad district of the year 1994, 2004, 2014 and data collected from CMO office Allahabad.

Where, I = Institution, $\mathrm{S}=$ Sub-centres, $\mathrm{B}=$ Beds, D = Doctors, $\mathrm{P}=$ Para-medical Staffs, and O = Other Staffs

A couple of blocks namely, Shankargarh (21.44) and Meja, Manda (18.76) has somehow managed to get the second and third place in this section of health care but still they are far from the level of satisfaction in the year1994. The overall performance of availability of sub-centres has been gradually decreasing from 15.20, 14.08, 12.61 health sub-centres per lakh population in 1994, 2004 and 2014 respectively. All the development blocks have experienced decreasing trend except Uruwan and Soraon during 1994-2014. Availability of subcentres in these two blocks have increased from $12.94 \mathrm{SCs} / \mathrm{lakh}$ population to $13.26 \mathrm{SCs} / \mathrm{lakh}$ population in Uruwan and 12.74 SCs/lakh population to $12.94 \mathrm{SCs} /$ lakh population in Soraon development blocks. Highest decrease is found in the case of Kaurihar (-5.65 SC/lakh population) and Jasra (-4.77 SC/lakh population) development blocks during the year 1994 to 2014.

Hospital bed-population ratio: This reflects the number of hospital beds per lakh of population in each block. It is also an important health related indicator that ensures indoor clinical facility at the time of serious diseases or emergency. Considering the case of Allahabad district regarding the bed-population ratio, especially in the government sector, a total of 25.95 beds for every 100 thousand persons are available for the district as a whole in 1994. Variations in this ratio are large within the district. It varies from a maximum of 60.69 beds $/ 1,00,000$ population in Soraon to 6.62 beds/1,00,000 population in Bahria development block in 1994. The condition is extremely poor mainly due to lack of proper governmental initiatives (Table 1.5). The situation of availability of beds per lakh population in 1994 was better in development blocks namely, Soraon (60.69 beds per lakh population), Shankargarh (52.62 beds per lakh population), Jasra (49.82 beds per lakh population) and Manda (49.47 beds per lakh population). These high figures for bed strength in healthcare centres for above blocks may be attributed due to the low population as compaired to the other development blocks. The average number of available beds has decreased from 25.95 beds per lakh population in 1994 to 18.13 beds per lakh population in 2004 and 14.59 beds per lakh population in 2014 in Allahabad district as a whole. It is worthwhile to mention that increase in number of beds is not so significant during the last 20 years. Besides this many blocks show positive change in number of beds per lakh population like Bahria (6.62 to 13.93 beds per lakh population), Mauaima (11.85 to 20.45 beds per lakh population), Pratappur (10.64 to 18.69 beds per lakh population) and Dhanupur (7.93 to 17.21 beds per lakh population) excepting these all other blocks show negative change in number of beds per lakh population due to rapid increase in population.

Doctor-population ratio: It illustrates the quantitative assessment of dependency of population on the hospital doctors. Doctors are the base of the health care system in any region because every type of medical infrastructure is totally futile in the absence of adequate number of doctors. Rise in number of doctors increases the probability of getting better healthcare. The condition of Allahabad district in this regard is similar to other neighbouring districts. In the year 1994 the number of doctors per lakh population was 6.66 for the district as a whole. This ratio ranges from 3.96 doctors per lakh population in Dhanupur block to 11.69 doctors per lakh population in Shankargarh development blocks. There are three development blocks namely, Shankargarh (11.69), Jasra (10.68) and Meja (10.23) which have more than 10 doctors per lakh population. The number of doctors per lakh population has decreased considerably during the last 20 years. The regional value of doctors per lakh population has decreased to 3.95 in 2014 against 6.66 in 1994 for the district as a whole. The lowest number of doctors per lakh population in 2014 has been found in Holagarh block (1.64 doctors per lakh population) while the highest number is recorded in Handia development block (6.12 doctors per lakh population).

Para-medical Staff-Population Ratio: Contrary to the medical institution, sub-centres, beds, doctors available at per lakh population, availability of para-medical staffs have shown better picture for the study area. On an average availability of para-medical staff for per lakh population in 1994 was 5.70 which decreased 4.37 staff per lakh population and again it has increased to 8.09 para-medical staff per one lakh population in the district as a whole. The district shows regional variation in availability of para-medical staffs. It is maximum found (10.68) in Jasra block where as minimum (3.84) in Bahadurpur development blocks. During 1994 to 2004 district shows poor picture in availability of para-medical staff. It varies from 2.69 in Kaurihar block to 8.38 in Jasra block. Availability of para-medical staffs shows better condition in 2014 as compaired to the previous years of 1994 and 2004. In 2014 some of the blocks such as Handia (12.70), Shankargarh (11.62), Jasra (11.07), Soraon (10.87) and Manda (10.13) etc. enjoys better health care facilities in terms of para-medical staffs. Handia 
development block (12.70 para-medical staff per lakh population) is the most developed in this regard. On the other hand, Kaurihar (4.83), Bahadurpur (5.08), Bahria (5.13), and Pratappur (5.34) have poor medical facility in terms of para-medical staffs in the district.

Other staff-population ratio: On an average availability of other staff for one lakh population in 1994 was 7.94 which decreased 5.89 staff per lakh population and again it has increased to 14.44 other staff per lakh population in the district as a whole. District shows regional variation in availability of other staffs. It varies from 5.52 in Bahria to 14.24 in Jasra block. During 1994 to 2004 district shows poor performance in availability of other staff and varies from 3.23 in Kaurihar block to 10.33 in Shankargarh block in the year 2004. Availability of other staffs shows better condition in the year 2014 as compaired to previous years of 1994 and 2004. In 2014 some of the blocks such as Soraon (24.33), Holagarh (22.44), Mauaima (22.06), Jasra (19.22) and Chaka (18.60) etc. enjoys better health care facilities in terms of other staffs. Soraon development block (24.33 other staff per lakh population) is the most developed in this regard. On the other hand, Koraon (8.84), Dhanupur (9.46), and Manda (9.62) have poor facility in terms of other staffs in the district. This aspect certainly attracts the attention of policy makers and provides a clue to improve the healthcare facilities in the study area.

\section{INFRASTRUCTURAL GAPS FOLLOWING EXISTING NATIONAL NORMS Rural health infrastructure and shortfall}

According to the provision of public healthcare infrastructure in India, ensuring equity in access to all population sub-groups has been the central theme. For this reason, the healthcare facilities across country their number and location have been defined in terms of population norms. According to the norm there should be one Sub-centre (SC) for every 5,000 population (3,000 population in case of hilly and tribal areas), one Primary Health Centre (PHC) for every 30,000 population and one Community Health Centre (or Rural Hospital) (CHC or $\mathrm{RH}$ ) for every 100,000 to $1,20,000$ population. In Allahabad district, the population density varies significantly across the blocks. The physical strength of public healthcare institutions and health care personnel in Allahabad district do not appear to be substantially enough than the healthcare resources supplied to the less populated blocks in the district. Because of these factors, the system loads borne by lower level healthcare institutions are unequal and limiting the access of the people on the one hand and affecting the quality and delivery of healthcare services on the other. The above analysis indicates that there is scope to improve the situation with respect to the provisioning of health infrastructure. This raises the question as to what extent the existing set up must be expanded. In this section attempt has been made to estimate the number of additional Sub Centres, and PHCs required in the district. Based on the national norms for provision of health infrastructure, the number of such units required in each block has been estimated. It is then compared with the actual number of units currently existing to measure the infrastructural gap. Thus, analysis of such block level disparity in health care infrastructure would help to identify specific deficiencies and suggest corrective measures to improve the health care system in the district.

Since population and the total number of healthcare institutions vary widely across different blocks of the district, the ratio between the population and the number of healthcare institutions such as BPHCs that provide both in-patient and out-patient facility and PHCs and SCs that basically provide out-patient care, also vary substantially. It is worth noting that out of 70 PHCs in the district, all PHCs have necessary infrastructure to provide in-patient care. Though every PHC in the district serves about 50,000 persons, which indicates moderate system load, the distribution is extremely uneven - ranges from as high as 1,10,224 persons per PHC in Chaka to about 28,617 in Jasra. Other PHCs which have very high system load include the PHCs belonging to Mauaima, Holagarh, Bahria, Kaurihar, Karchhana and Dhanupur blocks. PHCs of these blocks have to bear very high system load as these PHCs serve densely populated areas of the district. Because of the high system load on the PHCs of these blocks, patients are often compelled to travel to the BPHCs or nearby RHs or SDHs not only for in-patient care but also to obtain out-patient care, which in turn increases the system load on the higher level of healthcare facilities. They have no other choice but to go to the private nursing homes and other providers to seek treatment in the subdivisions and district headquarter if they don't find any place in the overloaded RHs or SDHs. Although nowhere in the country it is found that the desired national norm of PHCpopulation ratio is satisfied, yet other blocks in the district have a more favourable number of PHC to population ratio as compared to the blocks mentioned above. As indicated, Jasra development block holds the best position in terms of PHC-population ratio followed by Meja, Manda and Shankargarh blocks.

The study reveals that there is imbalance between healthcare facilities existing in blocks and the current population of the corresponding blocks. On the whole, each block of the district should be served by more than 3 PHCs under the existing national norms instead of the present average per block, which is approximately 5 per block. In regional terms, the largest shortfall in the number of PHCs is observed in the most populous Bahria block followed by Holagarh, Mauaima, Phulpur, Dhanupur, Chaka and Karchhana in the district. Bahria block requires 3 additional PHCs and other aforesaid blocks require another 2 PHCs each under the existing norm. On 
the other hand blocks having lower number of PHCs are Soraon, Bahadurpur, Pratappur, Saidabad and Handia. Each of these blocks requires one additional PHC as per the existing PHC-population norms, whereas, four blocks Jasra (2), followed by Shankargarh, Meja and Manda (1 each) have excess number of PHCs than required in 1994.

The health infrastructure in most of the blocks is characterized by varying extent of deficiencies. Only in the case of PHCs in Jasra, Manda, Meja and Shankargarh blocks there was surplus number of PHCs in 1994. But as the time passes this situation is going to become worse. There was shortfall of 45 PHCs in Allahabad district as a whole during 1994-04. Most of the blocks reported high deficit. Only Handia and Jasra development blocks reported no shortfall of PHC because of the establishment of 2 new PHCs during this period. Highest deficit is found in the case of Kaurihar block (-6) followed by Bahria (-5), Holagarh (-3), and Karchhana (-3), ect. Moreover, this deficit has increased upto -81 PHCs (existing 70 and required 151) during 2004-14 decade.

Table 1.6: Availability of PHCs and Sub - centers according to Population Norms of IPHS Guidelines

(1994 - 2014)

\begin{tabular}{|c|c|c|c|c|c|c|c|c|c|c|c|c|c|c|c|c|c|c|}
\hline \multirow{4}{*}{$\begin{array}{l}\text { Block } \\
\text { Name }\end{array}$} & \multicolumn{18}{|c|}{ Availability of PHCs and Sub - centers according to Population Norms of IPHS (1994 - 2014) } \\
\hline & \multicolumn{6}{|c|}{1994} & \multicolumn{6}{|c|}{2004} & \multicolumn{6}{|c|}{2014} \\
\hline & \multicolumn{3}{|c|}{$\begin{array}{l}\text { PHC/30,000 } \\
\text { Pop. }\end{array}$} & \multicolumn{3}{|c|}{ SC/5,000 Pop. } & \multicolumn{3}{|c|}{$\begin{array}{c}\text { PHC/30,000 } \\
\text { Pop. }\end{array}$} & \multicolumn{3}{|c|}{ SC/5,000 Pop. } & \multicolumn{3}{|c|}{$\begin{array}{c}\text { PHC/30,000 } \\
\text { Pop. }\end{array}$} & \multicolumn{3}{|c|}{ SC/5,000 Pop. } \\
\hline & $\mathbf{R}$ & $\mathbf{E}$ & $\mathbf{G}$ & $\mathbf{R}$ & $\mathbf{E}$ & $\mathbf{G}$ & $\mathbf{R}$ & $\mathbf{E}$ & G & $\mathbf{R}$ & $\mathbf{E}$ & $\mathbf{G}$ & $\mathbf{R}$ & E & G & $\mathbf{R}$ & $\mathbf{E}$ & $\mathbf{G}$ \\
\hline Kaurihar & 5 & 5 & 0 & 28 & 21 & -7 & 12 & 6 & -6 & 74 & 46 & -28 & 13 & 5 & -8 & 79 & 36 & -43 \\
\hline Holagarh & 4 & 2 & -2 & 25 & 22 & -3 & 5 & 2 & -3 & 31 & 26 & -5 & 6 & 2 & -4 & 37 & 28 & -9 \\
\hline Mauaima & 4 & 2 & -2 & 24 & 21 & -3 & 5 & 4 & -1 & 30 & 25 & -5 & 6 & 3 & -3 & 37 & 26 & -11 \\
\hline Soraon & 4 & 3 & -1 & 27 & 17 & -10 & 6 & 4 & -2 & 34 & 21 & -13 & 6 & 3 & -3 & 39 & 25 & -14 \\
\hline Bahria & 6 & 3 & -3 & 36 & 27 & -9 & 8 & 3 & -5 & 45 & 32 & -1 & 9 & 3 & -6 & 55 & 34 & -21 \\
\hline Phulpur & 5 & 3 & -2 & 30 & 22 & -8 & 6 & 3 & -3 & 38 & 25 & -13 & 8 & 2 & -6 & 45 & 28 & -17 \\
\hline Bahadurpur & 7 & 6 & -1 & 42 & 31 & -11 & 8 & 6 & -2 & 49 & 32 & -17 & 10 & 6 & -4 & 59 & 38 & -21 \\
\hline Pratappur & 5 & 4 & -1 & 30 & 22 & -8 & 6 & 5 & -1 & 37 & 25 & -12 & 7 & 5 & -2 & 45 & 28 & -17 \\
\hline Saidabad & 6 & 5 & -1 & 33 & 20 & -13 & 7 & 5 & -2 & 42 & 24 & -18 & 8 & 6 & -2 & 51 & 26 & -25 \\
\hline Dhanupur & 5 & 3 & -2 & 30 & 20 & -10 & 6 & 4 & -2 & 38 & 24 & -14 & 8 & 4 & -4 & 46 & 24 & -22 \\
\hline Handia & 5 & 4 & -1 & 28 & 18 & -10 & 6 & 6 & 0 & 34 & 21 & -13 & 7 & 5 & -2 & 43 & 23 & -20 \\
\hline Jasra & 4 & 6 & 2 & 22 & 25 & 3 & 5 & 5 & 0 & 29 & 29 & 0 & 6 & 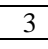 & -3 & 34 & 30 & -4 \\
\hline Shankargarh & 3 & 4 & 1 & 21 & 22 & 1 & 5 & 3 & -2 & 27 & 26 & -1 & 5 & 3 & -2 & 33 & 30 & -3 \\
\hline Chaka & 4 & 2 & -2 & 25 & 18 & -7 & 5 & 3 & -2 & 28 & 22 & -6 & 7 & 2 & -5 & 44 & 26 & -18 \\
\hline Karchhana & 5 & 3 & -2 & 31 & 21 & -10 & 7 & 4 & -3 & 45 & 23 & -22 & 8 & 3 & -5 & 47 & 29 & -18 \\
\hline Kaudhiyara & 3 & 3 & 0 & 20 & 19 & -1 & 4 & 1 & -3 & 25 & 26 & 1 & 5 & 1 & -4 & 32 & 24 & -8 \\
\hline Uruwan & 4 & 4 & 0 & 26 & 17 & -9 & 6 & 4 & -2 & 33 & 22 & -11 & 7 & 3 & -4 & 41 & 27 & -14 \\
\hline Meja & 4 & 5 & 1 & 23 & 22 & -1 & 5 & 4 & -1 & 32 & 28 & -4 & 7 & 3 & -4 & 39 & 28 & -11 \\
\hline Koraon & 6 & 6 & 0 & 37 & 20 & -17 & 8 & 5 & -3 & 45 & 28 & -17 & 11 & 5 & -6 & 63 & 34 & -29 \\
\hline Manda & 4 & 5 & 1 & 23 & 22 & -1 & 6 & 4 & -2 & 36 & 26 & -10 & 7 & 3 & -4 & 39 & 28 & -11 \\
\hline Total & 94 & 78 & $\overline{16}$ & 562 & 427 & $\overline{135}$ & 126 & 81 & $\overline{45}$ & 754 & 531 & $\overline{223}$ & 151 & 70 & $\overline{8}$ & 907 & 572 & $\overline{335}$ \\
\hline
\end{tabular}

Source: Calculated by the researcher from Statistical Handbook of Allahabad district of the year 1994, 2004, 2014 and data collected from CMO office Allahabad.

Where, $\mathrm{PHC}=$ Primary Health Centres, $\mathrm{SC}=$ Sub-centres, $\mathrm{R}=$ Required, $\mathrm{E}=$ Existing, and $\mathrm{G}=\mathrm{Gap}$.

In the year 2014, all development blocks face huge shortage of PHCs against the required number. Lowest deficit is found in Handia (-2), Pratappur (-2), Saidabad (-2) while it is found highest in Bahria (-6), Phulpur (-6) and Koraon (-6) development blocks of Allahabad district. As far as Sub-centres (SCs) are concerned, the highest shortfall in 1994 was observed in Koraon block (shortfall of 17) followed by Saidabad (shortfall of 13) and Bahadurpur (shortfall of 11). A number of blocks namely, Soraon, Dhanupur, Handia and Karchhana require additional 10 sub-centres under the existing norm. The most favourable position in terms of sub-centres per 5,000 populations is held by Jasra and Shankargarh, which has more sub-centres (3 and 1 respectively) than its requirement. The other three blocks which have low shortfall are Kaudhiyara, Meja, and Manda. On an average, every block needs at least 7 sub-centres to the existing ones. Table 1.6 depicts that the number of health sub-centres has increased from 427 to 531 during 1994-2004. Beside this growth, all the blocks experiences huge negative gap (deficit) in required sub-centres except Kaudhiyara (+1) and Jasra (0) development blocks. Highest deficit of sub-centres is found in Kaurihar (28) followed by Karchhana (22), Saidabad (18), Bahadurpur (17), Koraon (17) and Dhanupur development blocks in Allahabad district. Akin to this during 2004-14, the numbers of sub-centres have also increased from 531 in 2004 to 572 in 2014. But the 
availability of health sub-centres is more crucial with compared to previous decades. Over all there is deficit of 335 more sub-centres in the study area. In 2014 not a single development block reported to have surplus of subcentres. The requirements of such a significant number of sub-centres indicate that a very large section of rural population is deprived of basic healthcare, and they require travelling to nearby PHC or BPHC in order to obtain primary healthcare bearing direct and indirect costs.

On the whole, it may be inferred from the present analysis that there is a substantial gap in physical infrastructure as well as paucity of health personnel in the populous blocks of the district and require special attention. In the case of other blocks, it seems that the existing facilities are possibly adequate to meet current healthcare demand. It should also be kept in mind that due to such inadequacies of facilities a large section of the rural population may either seek alternative healthcare facilities from private practitioners (qualified or unqualified), traditional healers or simply do not seek any treatment due to variety of constraints factors.

\section{REQUIRED HEALTH CARE INFRASTRUCTURES IN ALLAHABAD DISTRICT}

Every action and reaction on the earth surface is bounded by the spatio-temporal framework. So without the space dimension every phenomenon is incomplete within itself. For analyzing the spatiality of health care in the Allahabad district following infrastructural parameters be included in the study:

\section{Community health centres}

Medical institution-population ratio is the expression of number of healthcare centres (includes Community Health Centers, Block Primary Health Centers, Government Hospitals, etc.) as per IPHS norms in different blocks of the district. This is perhaps the most important indicator in relation to the medical facility of a particular region. Increasing number of health centers always increases the probability of fast remedy from health related problems. But only a quantitative assessment such as the number of medical institution is not enough for the desired result, rather a quality assessment in terms of properly equipped medical centers (i.e. health related infrastructure) for better treatment facility is the most important. In case of Allahabad district, significant disparities exist at block level in terms of Community Health Centres-population ratio. The study area possesses a CHC for about 2,40,000 persons while the norms is much lower $(1,20,000)$ than existing situation. In order to fulfill the standard norms, 19 more CHCs are needed to be established, at least one in each development block except in Jasra, Shankargarh and kaudhiyara because these three development blocks have no shortfall of CHCs. Whereas, in Kaurihar, Holagarh and Koraon have deficit of 2 more CHCs and it should be established at different places according to the demand of population.

\section{Primary health centres}

According to the number of PHCs for the district as a whole, the situation is not satisfactory. In the study area a PHC is found for every 64,819 population. But the norm for establishment of PHC is much lower than the current position. Existing PHCs are also not homogeneously distributed in the different development blocks of Allahabad district. Hence there appears a shortage of 81 more PHCs in the area under study, which needs to be located at selected places. Highest number of PHC is required in Kaurihar (8) followed by Bahria, Phulpur, Koraon (6 PHC each) whereas 5 PHCs are needed in Chaka and Karchhana development blocks. Lowest shortfall (2 PHC) is found in four development blocks such as Pratappur, Saidabad, Shankargarh and Handia respectively.

\section{Sub Centres}

The district has 572 SCs catering the demand of healthcare facilities to around 45,37,359 lakh rural population (as per 2011 census). Thus, average population covered by one SC comes to around 7,932 against the norms of 5,000 (3,000 in tribal, hilly and backward areas). Thus on a normative basis there is shortage of more than 335 SCs, which should be established by splitting the jurisdictions of existing SCs with population coverage beyond norm. Highest numbers of SCs (43) are required in Kaurihar block followed by Koraon (29), Saidabad (25), Dhanupur (22), Bhadurpur (21), Bahria (21) and 20 in Handia development block. For instance, lowest shortage or required less number of SCs in Shankargarh (3) followed by Jasra (4), Kaudhiyara (8) and Holagarh (9) Development blocks in the study area. Most of the sub-centres need adequate infrastructure like room for examination of mothers, office room, delivery room (if delivery is decided to be conducted there), adequate space for waiting of the visiting mothers, running water supply, toilet, electricity etc. Also, each SC should be connected through all- weather road. The location of proposed CHCs, PHCs and Sub-centres have been suggested on the basis of gaps appearing in the demand regions, accessibility, population of village in gap areas and favorable sites looking into the topography and vegetation covers. 
Spatio-Temporal Analysis Of Health Care Facilities in Allahabad District: A Geographical Study

Table 1.7: Block wise Health Facilities Required Against Existing Institution and Population for 2014

\begin{tabular}{|c|c|c|c|c|c|c|c|c|c|c|}
\hline \multirow{4}{*}{ Block Name } & \multicolumn{10}{|c|}{ Block wise Health Facilities Required Against Existing Institution and Population for 2014} \\
\hline & \multicolumn{10}{|c|}{ Year 2014} \\
\hline & \multirow{2}{*}{$\begin{array}{c}\text { Total } \\
\text { Population }\end{array}$} & \multicolumn{2}{|r|}{ Existing } & \multicolumn{7}{|c|}{ Required } \\
\hline & & $\mathrm{CHCs}$ & $\begin{array}{c}\mathrm{CHC} / 1,20,000 \\
\text { Population }\end{array}$ & CHCs & PHCs & $\begin{array}{c}\text { Sub- } \\
\text { centres }\end{array}$ & Beds & Doctors & $\begin{array}{c}\text { Para- } \\
\text { Medical } \\
\text { Staffs }\end{array}$ & $\begin{array}{l}\text { Other } \\
\text { Staffs }\end{array}$ \\
\hline Kaurihar & 393551 & 1 & 0.3 & 3 & 13 & 79 & 168 & 62 & 141 & 104 \\
\hline Holagarh & 182703 & 0 & 0.0 & 2 & 6 & 37 & 96 & 36 & 78 & 56 \\
\hline Mauaima & 185851 & 1 & 0.6 & 2 & 6 & 37 & 96 & 36 & 78 & 56 \\
\hline Soraon & 193183 & 1 & 0.6 & 2 & 6 & 39 & 96 & 36 & 78 & 56 \\
\hline Bahria & 272779 & 1 & 0.4 & 2 & 9 & 55 & 114 & 42 & 96 & 71 \\
\hline Phulpur & 225021 & 1 & 0.5 & 2 & 8 & 45 & 108 & 40 & 90 & 66 \\
\hline Bahadurpur & 295501 & 1 & 0.4 & 2 & 10 & 59 & 120 & 44 & 102 & 76 \\
\hline Pratappur & 224729 & 1 & 0.5 & 2 & 7 & 45 & 102 & 38 & 84 & 61 \\
\hline Saidabad & 253166 & 1 & 0.5 & 2 & 8 & 51 & 108 & 40 & 90 & 66 \\
\hline Dhanupur & 232459 & 1 & 0.5 & 2 & 8 & 46 & 108 & 40 & 90 & 66 \\
\hline Handia & 212565 & 1 & 0.6 & 2 & 7 & 43 & 102 & 38 & 84 & 61 \\
\hline Jasra & 171702 & 1 & 0.7 & 1 & 6 & 34 & 66 & 24 & 57 & 43 \\
\hline Shankargarh & 163510 & 1 & 0.7 & 1 & 5 & 33 & 60 & 22 & 51 & 38 \\
\hline Chaka & 220448 & 1 & 0.5 & 2 & 7 & 44 & 102 & 38 & 84 & 61 \\
\hline Karchhana & 235625 & 1 & 0.5 & 2 & 8 & 47 & 108 & 40 & 90 & 66 \\
\hline Kaudhiyara & 159700 & 1 & 0.8 & 1 & 5 & 32 & 60 & 22 & 51 & 38 \\
\hline Uruwan & 203627 & 1 & 0.6 & 2 & 7 & 41 & 102 & 38 & 84 & 61 \\
\hline Meja & 197086 & 1 & 0.6 & 2 & 7 & 39 & 102 & 38 & 84 & 61 \\
\hline Koraon & 316734 & 1 & 0.4 & 3 & 11 & 63 & 156 & 58 & 129 & 94 \\
\hline Manda & 197419 & 1 & 0.6 & 2 & 7 & 39 & 102 & 38 & 84 & 61 \\
\hline Total & 4537359 & 19 & 0.5 & 38 & 151 & 907 & 2046 & 758 & 1704 & 1249 \\
\hline
\end{tabular}

Source: Calculated by the researcher from Statistical Handbook of Allahabad district of the year 1994, 2004, 2014 and data collected from CMO office Allahabad.

\section{Beds}

Availability of beds is an important indicator to know the intensity of inpatients situation of healthcare institutions as well as their strength. On an average bed population ratio is 1:6,854. There are only 662 beds available in different healthcare institutions in Allahabad district. Table 1.7 shows that, there is requirement of 2,046 more beds which shows lack of 1,384 beds in different development blocks of Allahabad district. Highest number of required bed are in Kaurihar block (168) followed by Koraon (156), Bahadurpur (120) and Bahria (114) development blocks. Whereas lowest requirement of beds is found in Kaudhiyara (60), Shankargarh (60 beds) followed by Jasra (66), Holagarh, Mauaima and Soraon development blocks needed 96 beds each respectively.

Doctors

Availability of doctors is directly proportional to the utilization of healthcare facilities because the doctors are called as the back-bone of healthcare system. On an average approximately 4 doctors are available for per lakh population, but their distribution is not homogeneous in the Allahabad district. Presently total of 179 doctors are providing their services in the district against 758 required number of doctors according to the existing IPHS norms. Among different development blocks highest number of required doctors is estimated in Kaurihar (62) followed by Koraon (58), Bahadurpur (44), Bahria (42) and Saidabad, Dhanupur, Karchhana block required 40 doctors each. While lowest requirement is found in Kaudhiyara, Shankargarh (22 doctors each block) followed by Jasra (24), Manda (38), Uruwan (38), Meja (38) and Handia (38) development blocks in Allahabad district.

\section{Paramedical staffs}

Para-medical staff plays an important role in smooth running of healthcare institutions because they help the doctor at the time of treatment and timely services provided to patients and people such as immunization and family welfare programmes. In 2014 there was only 367 para-medical staff working in different government hospitals/CHC/PHCs running in Allahabad district. The population para-medical staff 
ratio $(1: 12,363)$ is very high which is not sufficient to cover all the people. On an average there is requirement of 1,704 para-medical staff in Allahabad district which shows negative gap of 1,337 personals. Highest number of required para-medical staff is in Kaurihar block (141) followed by Koraon (129), Bahadurpur (102) and Bahria (96 development blocks. Whereas lowest requirement of para-medical staff is found in Kaudhiyara, Shankargarh (51 beds for each block) followed by Jasra (57), Holagarh, Mauaima and Soraon needed 78 paramedical staffs in each development blocks.

\section{Others}

Availability of other staff is another important indicator because they help in maintaining sanitation, hygiene, management and smooth running of the health plans designed by the health authorities and the government. There is requirement of 1,249 other staff for required CHC/PHC but at present the number of available other staffs is only 655. Shortage of other staff varies from one development block to another and their nature is not homogeneous over the region. Among different development blocks highest number of required other staffs is in Kaurihar (104) followed by Koraon (94), Bahadurpur (76), Bahria (71) and Saidabad, Dhanupur (56) and Karchhana development blocks has required 56 other staffs. While lowest requirement of other staff is found in Kaudhiyara, Shankargarh (38 doctors each block) followed by Jasra (43), Manda (61), Uruwan (61), Meja (61) and Handia (61) development blocks in the district

\section{ACCREDITED SOCIAL HEALTH ACTIVIST (ASHA)}

The Government of India has launch a National Rural Health Mission (NRHM) in 2005 to address the health needs of rural population, especially most vulnerable sections of the society. Currently Anganwadi Workers (AWWs) under the Integrated Child Development Scheme (ICDS) are engaged in organizing supplementary nutrition programmes and other supportive activities. The very nature of her job responsibilities (with emphasis on supplementary feeding and pre-school education) does not allow her to take up the responsibility of a change agent on health in a village. Thus a new brand of community based functionaries, named as Accredited Social Health Activist (ASHA) is proposed to fill this void. The ASHA is a female volunteer selected by the community, deployed in her own village (one in every 1000 population) after a short training on community health(MoHFW, 2005). Table 1.8 shows block wise status of ASHA workers in the district.The ASHA workers will be trained to advise village people about sanitation, hygiene, contraception, immunization and to provide primary medical care for diarrhoea, minor injuries, and fevers; and to escort patients to medical centres. They would also be expected to deliver direct observed short course therapy for tuberculosis and oral rehydration, to give folic acid tablets and chloroquine to patients, and to alert authorities of unusual outbreaks of diseases. ASHA will receive performance-based compensation for promoting universal immunization, referral and escort services for $\mathrm{RCH}$, construction of household toilets, and other health care delivery programmes.

Table 1.8: Block wise Status of ASHA in Allahabad District (2015)

\begin{tabular}{|l|l|c|c|c|}
\hline \multicolumn{1}{|c|}{ Sl. No. } & \multicolumn{1}{|c|}{ Target } & Total Trained & Shortfall \\
\hline 1 & Kurihar & 198 & 193 & -5 \\
\hline 2 & Holagarh & 170 & 165 & -5 \\
\hline 3 & Soraon & 173 & 164 & -9 \\
\hline 4 & Mauaima & 190 & 155 & -35 \\
\hline 5 & Bahariya & 191 & 185 & -6 \\
\hline 6 & Phulpur & 214 & 180 & -34 \\
\hline 7 & Pratappur & 151 & 146 & -5 \\
\hline 8 & Dhanupur & 231 & 227 & -4 \\
\hline 9 & Handia & 221 & 195 & -26 \\
\hline 10 & Saidabad & 210 & 204 & -6 \\
\hline 11 & Kotwan & 325 & 270 & -55 \\
\hline 12 & Chaka & 165 & 150 & -15 \\
\hline 13 & Jasra & 184 & 180 & -4 \\
\hline 14 & Shankergarh & 170 & 150 & -20 \\
\hline 15 & Kaundhiyara & 103 & 90 & -13 \\
\hline 16 & Karchhana & 284 & 240 & -44 \\
\hline 17 & Ram Nagar & 186 & 180 & -6 \\
\hline 18 & Meja & 130 & 121 & -9 \\
\hline 19 & Manda & 153 & 245 & -16 \\
\hline 20 & Koraon & 245 & 3,577 & -0 \\
\hline & Total & 3,894 & & -317 \\
\hline
\end{tabular}

Source: Secondary data collected from CMO office Allahabad and analysed by researcher (2015).

Table 1.8 clearly evinces that there is shortfall of about 317 ASHA (8.14\%) workers in the study area. A total of 3,894 ASHA workers have been targeted for training at different CHC/PHC and D. type of healthcare 
centres, but the district has failed to achieve their goal. Only 3,577 ASHA workers are getting training. This number varies from one block to another. All the development blocks are facing shortfall in terms of ASHA workers excepting Koraon which have achieved their target of giving training to ASHA workers. Highest shortfall of trained ASHA workers is found in Kotwan (-55) followed by Karchhana (-44), Mauaima (-35), Phulpur (-34) and Handia blocks (-26), etc.

\section{CONCLUSION}

For ensuring good health for all, the study area in particular and the country in general needs adequate extension of health care services, including health infrastructural facilities and services at CHC, PHC and Subcentres; availability of doctors (male and female); and residential quarters for doctors and para medical staffs that are appointed at every rural based centres. To improve the people's health the availability of doctor is must at all health centres. The government has to improve the management information system and accountability mechanism substantially so that the health professionals could perform their functions adequately and honestly. This will require improvement of management capacities in the health care systems at various levels through training and creating new posts of management positions.

\section{REFERENCES}

[1] Dreze J. and Sen A., 2005. India Development and Participation, Oxford University Press, New Delhi

[2] Baru R., Acharya A., Acharya S., Shiva Kumar A.K. And Nagraj K., 2010. Inequalities in Access to Health Services in India: Caste, Class and Region, Economic and political Weekly, Vol. 65 (38), Pp. 2842.

[3] Rajeshwari and Sinha S., 2004. Spatial Inequalities in the development of Public Health Care Facilities in Rural Haryana, India: Health Care Patterns and Planning edited by Akhtar R., A P H Publishing Corporation, New Delhi.

[4] Pandurkar, R.G., 1981. "Spatial Distribution of some Diseases in Maharashtra- A study in Medical Geography", Unpublished ph. D. Thesis, Shivaji University, Kolhapur.

[5] Duggal, Ravi and et. All, 2005. "Health and Health Care in Maharashtra: A Status Report", P.3.

[6] MOHFW, 2005. National Rural Health Mission: Framework for Implementation (2005-2012), Ministry of Health and Family Welfare, Govt. of India, New Delhi.

[7] District Statistical Handbook 1994, 2004 and 2014, Allahabad.

[8] Primary Census Abstract 1991, 2001 and 2011, Allahabad District.

[9] Office of Chief Medical Officer, District Allahabad, 2015. 